Abstracta Iranica

Revue bibliographique pour le domaine irano-aryen

Volume 23 | 2002

Comptes rendus des publications de $\mathbf{2 0 0 0}$

\title{
« Naqd-e pedar-e sālāne ». Našr-e Dāneš, 17, 1 (1379/2000), pp. 47-56.
}

\section{Charles-Henri de Fouchécour}

\section{(2) OpenEdition}

1 Journals

Édition électronique

URL : http://journals.openedition.org/abstractairanica/35784

DOI : 10.4000/abstractairanica.35784

ISSN : 1961-960X

\section{Éditeur :}

CNRS (UMR 7528 Mondes iraniens et indiens), Éditions de l'IFRI

\section{Édition imprimée}

Date de publication : 15 mai 2002

ISSN : 0240-8910

\section{Référence électronique}

Charles-Henri de Fouchécour, « « Naqd-e pedar-e sālāne ». Našr-e Dāneš, 17, 1 (1379/2000),

pp. 47-56. », Abstracta Iranica [En ligne], Volume 23 | 2002, document 257, mis en ligne le 08 février 2010, consulté le 25 septembre 2020. URL : http://journals.openedition.org/abstractairanica/35784 ; DOI : https://doi.org/10.4000/abstractairanica.35784

Ce document a été généré automatiquement le 25 septembre 2020.

Tous droits réservés 


\title{
« Naqd-e pedar-e sālāne ». Našr-e Dāneš, 17, 1 (1379/2000), pp. 47-56.
}

\author{
Charles-Henri de Fouchécour
}

L'auteur répond à deux articles, de B. Horramšāhī et de 'Alī Šarī'at Kāšānī, qui avaient pris à parti l'ouvrage de Dāryūš Āšūrī, Hastī-šenāsi-e Hââez (voir Abs. Ir., 20-21, n 610), lui reprochant son manque d'esprit critique, puisque l'ouvrage tentait de prouver la thèse traditionnelle du caractère entièrement mystique du Dīvān de Hāfeẓ. L'A. s'emploie à défendre le point de vue de D. Āšūrī, montrant en quoi il est 'moderne'. Il reproche à la thèse de Horramšāhī, pour qui Hāfez n'est ni vraiment mystique, ni vraiment et seulement 'terrestre', de ne pas répondre à la question de savoir pourquoi il y a cette contradiction chez Hāfeẓ. C'est au contraire le mérite de D. Āšūrī d'avoir affronté cette question. Pour D. Āšūrī, toute la réalité seulement humaine dont Hāfez traite est toujours énoncée avec la conviction qu'elle est un écho de la réalité éternelle, qui est le véritable enjeu. L'apport original de D. Āšūrī, selon l'A., est d'avoir montré que la réalité terrestre est miroir de l'éternelle.

\section{INDEX}

Thèmes : 11.1.1. Littérature persane classique

\section{AUTEURS}

\section{CHARLES-HENRI DE FOUCHÉCOUR}

Sorbonne Nouvelle - Paris III 